\title{
Correlation of Serum Unconjugated Oestriol to Red Cell 2,3-Diphosphoglycerate Levels in Diabetic Pregnancy
}

\author{
H. Madsen and J. Ditzel \\ Section of Endocrinology and Metabolism Department of Medicine, Department of Obstetrics and Gynecology \\ and Department of Clinical Chemistry, Aalborg Regional Hospital, Denmark
}

\begin{abstract}
Summary. In order to evaluate the possible underlying factors for the increase in red cell 2,3-diphosphoglycerate content observed in late diabetic pregnancy, its relationship with serum unconjugated oestriol, human placental lactogen, haemoglobin and hydrogen ion concentrations was investigated in 42 pregnant diabetic women. A significant correlation was found between red cell 2,3-diphosphoglycerate and serum unconjugated oestriol ( $r=0.54, p<0.001$ ), whereas no correlation was present between 2,3-diphosphoglycerate and the following variables: arterial $\mathrm{pH}$, haemoglobin concentration and human placental lactogen. The content of 2,3-diphosphoglycerate
\end{abstract}

correlated significantly with haemoglobin-oxygen affinity expressed as $\mathrm{P}_{50}$ at $\mathrm{pH} 7.4(r=0.34, p<0.05)$. The results of this study indicate that serum unconjugated oestriol may participate in the regulation of red cell 2,3-diphosphoglycerate content and thereby of the maternal blood oxygen release to the fetus.

Key words: Diabetic pregnancy, 2,3-diphosphoglycerate, serum unconjugated oestriol, oxyhaemoglobin dissociation curve.
It is well established that red cell 2,3-diphosphoglycerate $(2,3-\mathrm{DPG})$ is an important regulator of red cell oxygen release $[1,2]$. Increased levels of red cell 2,3-DPG shift the oxyhaemoglobin dissociation curve of blood to the right, thus facilitating the unloading of oxygen at the tissue level.

Red cell 2,3-DPG has been found to be increased during normal pregnancy [3-5]. In the third trimester the concentration of red cell 2,3-DPG may be elevated some $30 \%$ compared with non-pregnant women [3]. Recently we found, in a comparable study of non-smoking pregnant diabetic women, that their content of red cell 2,3-DPG was even further raised (17.8 versus $15.9 \mathrm{umol} / \mathrm{g}$ haemoglobin, $p<0.01$ ) [6].

Steroid hormones, such as hydrocortisone, aldosterone and androgens may stimulate red cell 2,3-DPG synthesis [7-9]. We therefore decided to search for a correlation of red cell 2,3-DPG with serum unconjugated oestriol, and other blood variables in the late pregnancy of diabetic subjects.

\section{Patients and Methods}

Forty-two Type 1 (insulin-dependent) pregnant diabetic women were studied in the third trimester between weeks $30-36$ of gestation. The median age of the patients was 26 years (range 19-43 years) and known median duration of diabetes was 11 years (range 3 months to 23 years). In two of the pregnant women, diabetes was diagnosed during pregnancy and both remained insulin-dependent post partum. Thirteen were classified in White class B, 14 in White class C, 13 in White class $D$ and two in White class F. Fourteen women were nonsmokers and 28 were smokers. None of the patients had severe anaemia, infections or suffered from cardiac, respiratory or renal insufficiency. The diabetes was treated according to the scheme of Pedersen [10]. The patients were given five daily meals. Thirty-seven received two insulin injections while the remaining five received one injection per day; usually a small amount of crystalline insulin mixed with NPH insulin.

Venous blood samples for determination of red cell 2,3-DPG, haemoglobin $\mathrm{A}_{1 \mathrm{c}}\left(\mathrm{HbA}_{1 \mathrm{c}}\right)$, serum unconjugated oestriol, human placental lactogen, haemoglobin concentration and oxyhaemoglobin affinity were taken in the morning $30 \mathrm{~min}$ after the usual morning insulin dose and a light breakfast. Red cell 2,3-DPG concentration was determined by an enzymatic method according to Ericsson and de Verdier [11]. The inter-assay variation was $2.1 \%$. Red cell 2,3-DPG was expressed as $\mu \mathrm{mol} / \mathrm{g}$ haemoglobin and $\mu \mathrm{mol} / 100 \mathrm{ml}$ whole blood. The level of $\mathrm{HbA}_{1 \mathrm{c}}$ was determined by the macro-column chromatographic method of Trivelli et al. [12] as modified by Schwartz et al. [13]. The haemolysates were dialyzed for $18 \mathrm{~h}$ at $4{ }^{\circ} \mathrm{C}$ against $1000 \mathrm{vol}-$ ume of glucose-free phosphate buffer ( $\mathrm{pH}$ 6.7). Bio Rex-70 was used as an ion exchange resin and the column was water-jacketed to maintain $25^{\circ} \mathrm{C}$. The inter-assay variation by this method in our laboratory was $2.5 \%$. The haemoglobin concentration was measured by means of a Coulter Counter S (Coulter Electronics, Dunstable, UK). The interassay variation was $1.2 \%$. Oxyhaemoglobin dissociation curves on heparinized whole blood were run in a Radiometer DCA-1 apparatus (Radiometer A $\mathrm{S}$, Copenhagen, Denmark), the principles of which 
Table 1. Median values and ranges in 42 insulin-dependent pregnant diabetic women and 20 healthy pregnant women

\begin{tabular}{|c|c|c|c|}
\hline & \multirow{2}{*}{$\begin{array}{l}\text { Healthy } \\
\text { pregnant } \\
\text { women }\end{array}$} & \multicolumn{2}{|c|}{ Pregnant diabetic women } \\
\hline & & Median & Range \\
\hline 2,3-DPG (umol/g haemoglobin) & 15.9 & 16.8 & $13.7-20.4$ \\
\hline 2,3-DPG $(\mu \mathrm{mol} / 100 \mathrm{ml})$ & 186 & 217 & $169-280$ \\
\hline $\mathrm{pH}$ & 7.46 & 7.44 & $7.36-7.47$ \\
\hline Haemoglobin $(\mathrm{g} / 100 \mathrm{ml})$ & 12.2 & 12.9 & $10.0-15.9$ \\
\hline $\mathrm{P}_{50}$ at $7.40(\mathrm{mmHg})$ & 28.1 & 27.1 & $22.8-29.7$ \\
\hline $\mathrm{P}_{50}$ at actual $\mathrm{pH}(\mathrm{mmHg})$ & 26.7 & 26.2 & $21.8-29.0$ \\
\hline Serum oestriol $(\mathrm{nmol} / \mathrm{l})$ & 30 & 36 & $19-89$ \\
\hline Human placental lactogen (mg/l) & 6.0 & 6.9 & $4.0-16.6$ \\
\hline $\mathrm{HbA}_{\mathrm{Tc}}$ (\% of total haemoglobin) & 3.9 & 7.3 & $5.0-9.9$ \\
\hline
\end{tabular}

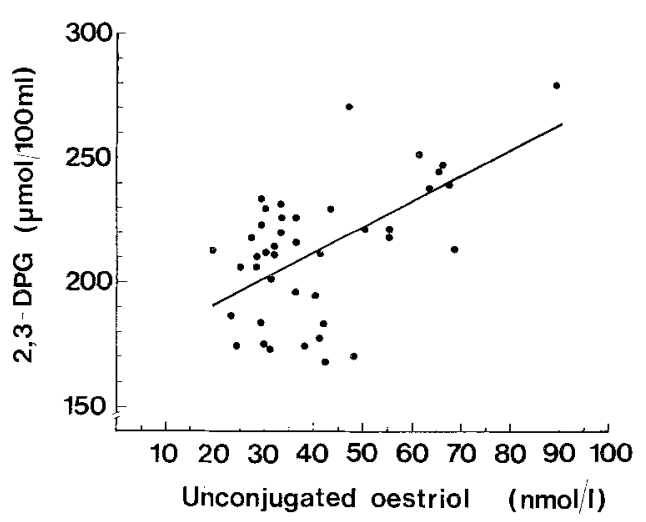

Fig. 1. Correlation between serum unconjugated oestriol and red cell 2,3-DPG in 42 pregnant diabetic women in the third trimester of pregnancy $(y=0.94 x+175, r=0.54, p<0.001)$.

have been described by Duvelleroy et al. [14]. The oxyhaemoglobin dissociation curve is the characteristic sigmoid shaped curve, which appears when the fractional saturation of haemoglobin with oxygen is plotted against oxygen tension. Oxygen affinity was expressed as $\mathbf{P}_{50}$ (i.e. $\mathrm{PO}_{2}$ at $50 \%$ oxygen saturation) at $\mathrm{pH} 7.4$ and at actual $\mathrm{pH}$ using the Bohr factor -0.38 [15]. Serum unconjugated oestriol was estimated by double determinations with the commercial Amerlex Oestriol (unconjugated) radioimmunoassay kit (Amersham International, Amersham, UK). The inter-assay variation was $8 \%$. Placental lactogen was measured in duplicate according to Nørgaard-Pedersen and Gæde [16]. The inter-assay variation was $6 \%$.

The statistical method used consisted of a multiple regression analysis.

\section{Results}

Table 1 presents median values and ranges of the measured variables in the 42 pregnant diabetic women. For comparison, the values in 20 healthy pregnant women studied in the third trimester are also given [6]. Using multiple regression analysis, a significant positive correlation was found between red cell 2,3-DPG and serum unconjugated oestriol, both when 2,3-DPG was expressed in $\mu \mathrm{mol} / \mathrm{g}$ haemoglobin $(r=0.53, p<0.001)$ and when expressed in $\mu \mathrm{mol} / 100 \mathrm{ml}$ whole blood $(r=0.54$, $p<0.001$; Fig. 1). Keeping unconjugated oestriol constant in the regression analysis red cell 2,3-DPG did not correlate with $\mathrm{pH}(r=0.26, \mathrm{NS})$, haemoglobin concentration $(r=0.16, \mathrm{NS})$ or with human placental lactogen $(r=0.002$, NS). Red cell $2,3-\mathrm{DPG}$ correlated significantly with $\mathrm{P}_{50}$ of the oxyhaemoglobin dissociation curve at $\mathrm{pH} 7.4(r=0.34, p<0.05)$. There was a significant correlation between human placental lactogen and serum unconjugated oestriol $(r=0.43, p<0.01)$. Serum unconjugated oestriol did not correlate with $\mathrm{HbA}_{1 \mathrm{c}}(r=0.22$, NS).

\section{Discussion}

In the present study we found a significant positive correlation of red cell 2,3-DPG with serum unconjugated oestriol in diabetic pregnancy. The formation of serum unconjugated oestriol in the third trimester is almost entirely produced by the feto-placental unit. The finding of a positive correlation between serum level of unconjugated oestriol and red cell 2,3-DPG may suggest that oestrogenic substances influence the level of red cell 2,3-DPG. Bleicher and Pang [4] briefly commented on the possibility of such a relationship based on the observations of elevated red cell 2,3-DPG in healthy pregnant women and in women on combined oestrogen-progestogen oral contraceptives. No relationship was found between red cell 2,3-DPG, pH and the haemoglobin concentration and it is unlikely that these variables influence 2,3-DPG in this situation.

The raised level of red cell 2,3-DPG may increase the capacity of the red cell to release oxygen [17]. This is supported by our finding of a correlation between the 2,3-DPG content and the $P_{50}$ of the oxyhaemoglobin dissociation curve. Thus the level of serum unconjugated oestriol indirectly may participate in determining maternal oxygen release to the fetus. Our observation of a relationship between 2,3-DPG and serum unconjugated oestriol may also be consistent with the finding that patients with placental insufficiency, who often show low levels of serum unconjugated oestriol, tend to have low levels of red cell 2,3-DPG [18]. From studies in vitro it has been shown that other steroid hormones may increase the level of red cell 2,3-DPG, such as hydrocortisone [7], aldosterone [8] and androgens [9]. The mechanism by which these steroids, as well as unconjugated oestriol, increase the concentration of red cell 2,3-DPG is not known.

In conclusion, we found that the increased level of red cell 2,3-DPG in late diabetic pregnancy was correlated with the concentration of serum unconjugated oestriol, suggesting that serum unconjugated oestriol may participate in determining the maternal oxygen release to the fetus in diabetic pregnancy.

Acknowledgements. This investigation was supported in part by the Northern Jutland Medical Research Fund and the Research Fund of Aalborg City Council. The technical assistance of E. Ditzel, G. Dahl Hansen, B.Søndergaard Jensen and H. Krigslund is gratefully acknowledged. 


\section{References}

1. Benesch R, Benesch RE (1967) The effect of organic phosphates from the human erythrocytes on the allosteric properties of hemoglobin. Biochem Biophys Res Commun 26: 162-167

2. Chanutin A, Curnish RR (1967) Effect of organic and inorganic phosphates on the oxygen equilibrium of human erythrocytes. Arch Biochem 121: 96-102

3. Rørth M, Bille Brahe NE (1971) 2,3-diphosphoglycerate and creatine in the red cell during human pregnancy. Scand J Clin Lab Invest 28: 271-276

4. Bleicher SJ, Pang S-J (1975) Oxygen transport and the role of erythrocyte 2,3-diphosphoglycerate. In: Camerini-Davalos RA, Cole HS (eds) Early Diabetes in Early Life. Academic Press, New York, London, pp 243-249

5. MacDonald RG, MacDonald HN (1977) Erythrocyte 2,3-diphosphoglycerate and associated haematological parameters during the menstrual cycle and pregnancy. Br J Obstet Gynaecol 84: 427-433

6. Madsen H, Ditzel J (1982) Changes in red blood cell oxygen transport in diabetic pregnancy. Am J Obstet Gynecol 143: 421-424

7. Petty C, Bageant T (1974) In vitro manipulation of 2,3-diphosphoglycerate levels in acid-citrate-dextrose blood with steroids. Life Sciences 14: 1279-1283.

8. Böning D, Meier U, Skipka W, Külpmann WR,Meurer KA (1976) Some evidence for aldosterone action on 2,3-diphosphoglycerate levels in human red cells. Metabolism 25:9-14

9. Molinari PF, Chung SK, Snyder LM (1973) Variations of erythrocyte glycolysis following androgens. J Lab Clin Med 81: 443-446

10. Pedersen J (1977) The pregnant diabetic and her newborn, 2nd edit. Munksgaard, Copenhagen, pp 221-232

11. Ericsson A, de Verdier CH (1972) A modified method for the de- termination of 2,3-diphosphoglycerate in erythrocytes. Scand J Clin Lab Invest 29: 85-90

12. Trivelli LA, Ranney HM, Lai HT (1971) Hemoglobin components in patients with diabetes mellitus. N Engl J Med 284: 353-357

13. Schwartz HC, King KC, Schwartz AL, Edmunds D, Schwartz K (1976) Effects of pregnancy on hemoglobin $A_{1 c}$ in normal, gestational diabetic and diabetic women. Diabetes 25: 1118-1122

14. Duvelleroy MA, Buckles RC, Rosenkaimer S, Tung C, Laver MA (1970) An oxyhemoglobin dissociation analyzer. J Appl Physiol 28:227-233

15. Arturson G, Garby L, Robert M, Zaar B (1974) The oxygen dissociation curve of normal human blood with special reference to the influence of physiological effector ligands. Scand J Clin Lab Invest $34: 9-13$

16. Nørgaard-Pedersen B, Grde P (1973) Immunoelectrophoretical quantitation of human placental lactogen hormone. Scand J Immunol (Suppl 1), 2: 129-131

17. Bellingham AJ, Detter JC, Lenfant C (1971) Regulatory mechanisms of hemoglobin oxygen affinity in acidosis and alkalosis. J Clin Invest 50: 700-706

18. MacLennan AH, Emerson PM, Hunter DJS, Darley JH (1976) Tissue oxygenation and red cell 2,3-diphosphoglycerate in normal and abnormal pregnancy. Br J Obstet Gynaecol 83: 378-382

Received: 26 April 1982

and in revised form: 14 October 1982

Dr. J. Ditzel

Section of Endocrinology

Department of Medicine

Aalborg Regional Hospital

DK-9000 Aalborg, Denmark 